\title{
In vivo antitumor potential of extracts from different parts of Bauhinia variegata linn. Against b16f10 melanoma tumour model in $\mathrm{c} 57 \mathrm{bl} / 6$ mice
}

Sonam Pandey ${ }^{1,2}$

\begin{abstract}
Background: Melanoma is a metastatic type of skin cancer that is difficult to treat and the majority of efforts are directed to the design of new drugs. Medicinal Plants have been the primary source of medicines since life on earth; more than $50 \%$ of existing cancer treatments is derived from plants. Bauhinia variegata is well-known medicinal plant used from the ancient era to till date for their medicinal values. Scientific literatures have not documented any evidence of the antitumour potential of Bauhinia variegata against B16F10 melanoma tumor model in C57BL mice. The present investigation was undertaken to explore the antitumour activity of Leaf, stem bark and flower extract of Bauhinia variegata against B16F10 melanoma tumour model in C57BL mice.

Methods: Hydro-methanolic extract prepared from the leaf, stem bark and flower of Bauhinia variegata were assessed for their antitumor activity. The extracts at doses of 500 and $750 \mathrm{mg} / \mathrm{kg}$ b.wt. were given orally along with cyclophosphamide (chemotherapeutic drug) for 40 days for exploring antitumor activity against melanoma tumor (B16F10) in C57BL mice. Inhibition of tumor growth, increase in survival time of animal with treatment, histopathological studies and antioxidant parameter were determined.

Results: The Present investigation showed significant effect of the $B$. variegata $\mathrm{L}$. in preventing melanoma tumor by B16F10 cell line in C57BL/6 mice. As compared with the tumour control group, the remarkable results especially in the group which received B. variegata extract and cyclophosphamide together were obtained for all of the measured parameters. Dose dependent response was observed in tumor volume, inhibition rate, life span time and antioxidant parameter of extracts. Combination treatment of cyclophosphamide and B. variegata extracts showed more pronounced effect.

Conclusions: These findings suggest that $B$. variegata hydromethanolic extract may contain bioactive compounds of potential therapeutic significance which are relatively safe from toxic effects, and can compromise the medicinal use of this plant in folk medicine.
\end{abstract}

Keywords: Chemoprevention, Bauhinia variegata, Melanoma, B16F10 cell line, GSH

\footnotetext{
Correspondence: sonam_research@ymail.com

${ }^{1}$ Gujarat State Biotechnology Mission, Gandhinagar, Gujarat, India

${ }^{2}$ Research Department, Jawaharlal Nehru Cancer Hospital and Research

Centre, Idgah Hills, Bhopal, Madhya Pradesh, India
} 


\section{Background}

Cancer is a growing health problem in both developing and developed countries. Melanoma is the most aggressive and deadly form of skin cancer. Patients with distant metastases have a five-year survival rate of $16 \%$ [1] and a median survival of four to six months [2]. Until very recently, melanoma has been branded by the failure of chemotherapy and other therapeutic attempts. Currently, the main treatments for cancer are chemotherapy, radiotherapy and surgery. Chemotherapy is routinely used for cancer treatment. Since cancer cells lose many of the regulatory functions present in normal cells, they continue to divide when normal cells do not. This feature makes cancer cells susceptible to chemotherapeutic drugs. Approximately five decades of systemic drug discovery and development have resulted in the establishment of a large collection of useful chemotherapeutic agents. Currently, some of these plant-derived compounds are widely used for chemotherapy of cancerous patients. However, chemotherapeutic treatments are not devoid of their own intrinsic problems. Various kinds of toxicities may occur as a result of chemotherapeutic treatments. For example, 5-fluorouracil, a common chemotherapeutic agent, is known to cause myelotoxicity [3], cardiotoxicity [4] and has even been shown to act as a vasospastic agent in rare but documented cases [5]. Another widely used chemodrug, doxorubicin causes cardiac toxicity [6-8], renal toxicity [9], and myelotoxicity. [10] Similarly, bleomycin a well-known chemotherapeutic agent, is known for its pulmonary toxicity [11-13]. In addition, bleomycin shows cutaneous toxicity [14]. Cyclophosphamide, a drug to treat many malignant conditions, has been shown to have bladder toxicity in the form of hemorrhagic cystitis, immunosuppression, alopecia and at high doses cardiotoxicity [15].

A major problem associated with cancer chemotherapy is the severe side effects resulting from normal tissue damage. Consequently, agents which protect normal tissues against chemotherapy can increase the patient's tolerance to chemotherapy. Several chemicals have been found to provide notable protection in experimental animals, but their clinical utility is limited by the drug toxicity on repeated administration [16]. Therefore, there is a need to find nontoxic and inexpensive drug/(s) for clinical chemo protection. Recent studies have indicated that some of the commonly used medicinal plants may be good source of potent but nontoxic chemoprotectors [17-20].

Natural products discovered from medicinal plants have played an important role in treatment of cancer, which is projected to become the major cause of death worldwide. A wide number of plant extracts are used against diseases in various systems of medicine such as Ayurveda, Unani and Siddha. Only a few of them have been scientifically explored. Plant derived natural products such as flavonoids, terpenes and alkaloids [21-23] and soon has received considerable attention in recent years, due to their diverse pharmacological properties including cytotoxic and cancer chemopreventive effects [24]. Plant based systems continue to play an essential role in healthcare and it has been estimated by WHO that approximately $80 \%$ of the world's inhabitants rely mainly on traditional medicine for their primary health care [25].

The use of natural products in cancer therapy showed that plants are a most important source of antitumor compounds, with new structures and mechanisms of action being discovered [26]. Several plant-derived products induce apoptosis in neoplastic cells but not in normal cells [27-29].

Bauhinia variegata (Family fabaceae, Genus Bauhinia) is an herbaceous plant, found throughout India. The plant is known as Kachnara in Sanskrit and Hindi. All parts of the plant (leaves, flower buds, flower, stem, stem bark, seeds and roots) were used in traditional medicine. For using various ailments like bronchitis, leprosy, and tumors. The stem bark was used as astringent, tonic, anthelmintic and antidiabetic [30]. Infusion of the leaves was used as a laxative and for piles. Dried buds were used in the treatment of worm infestations, tumors, diarrhea, and piles. It is helpful in managing skin discoloration [31-33].

The phytochemical screening revealed that Bauhinia variegata contained terpenoids, flavonoids, tannins, saponins, reducing sugars, steroids and cardiac glycosides. Pharmacological studies showed that Bauhinia variegata exerted anticancer, antioxidant, hypolipidemic, antimicrobial, anti-inflammatory, nephroprotective, hepatoprotective, antiulcer, immunomodulating, molluscicidal and wound healing effects $[34,35]$. Previous phytochemical studies on the stems [36-38], flowers [34, 39], leave and seeds [40, 41] of this species have led to the isolation of several flavonoids.

There are also a few reports of antitumor activity of $B$. variegata ethanolic extract against Dalton's ascetic lymphoma (DAL) in Swiss albino mice [42] and N-nitrosodiethylamine induced experimental liver tumors in rats and human cancer cell lines [43]. The present study evaluates the chemopreventive effect of the different parts and different doses of $B$. variegata on B16F10 melanoma tumor on C57BL mice.

\section{Methods}

\section{Animals}

The study was conducted on random bred, 6-7 weeks old and 24-28 g b.wt. bearing, male C57BL/6 mice. Animals were maintained under controlled conditions of temperature and light (Light: dark, $10 \mathrm{~h}: 14 \mathrm{~h}$.). They were provided standard mice feed (procured from Hindustan Levers Ltd.) and water ad libitum.

\section{Chemicals}

Reduced glutathione, Cyclophosphamide, 5,5'-dithiobis (2nitrobenzoic acid) (DTNB), Sodium citrate and other chemicals were procured from Sigma Chemical Co (St Louis, MO). 
Identification and collection of plant material

Aerial parts of $B$. variegata (Kachnar) like leaves, stem bark and floral bud were collected in the early stages of vegetation from the Bhopal, and Tah-Niwas, District Mandla (M.P.), India, during the month of October, 2007. The identification of the plant B. variegata L. (Kachnar) (family: Leguminose) was done by botanist Dr. S.S. Khan (Voucher Specimen No: SP/101/LGOB/2007), Department of Botany, Safia Science College, Bhopal, Madhya Pradesh (India).

\section{Preparation of $B$. variegata extract}

Shade dried powdered plant material such as leaves, stem bark and floral buds $(50 \mathrm{~g})$ were extracted by continuous mixing in $100 \mathrm{ml} \mathrm{50 \%} \mathrm{methanol,} \mathrm{and} \mathrm{stem} \mathrm{bark} \mathrm{in} \mathrm{95 \%}$ methanol, $24 \mathrm{~h}$ at room temperature. After filtration, methanol and water was evaporated at $60-70{ }^{\circ} \mathrm{C}$ temperature. The percentage yield of the crude extract was determined for each parts of B. variegata and was for leaf $12 \%$, stem work $20 \%$ and floral buds $10 \%$. The percentage extract yield was estimated as dry weight/dry material weight $\times 100$ [44]. The dried powder was kept in air tight box.

\section{Acute oral toxicity test (LD50) Experimental animals}

Acute oral toxicity test was performed as per Organization for Economic Co-operation and Development (OECD) guidelines 423 [45]. Experiments were performed using 54 male C57BL/6 mice were obtained from the Animal House of the Jawaharlal Nehru Cancer Hospital and Research Centre, Bhopal. The animals were randomly divided into nine groups of 6 animals per group.

\section{Administration dose}

Following the period of fasting, animals were weighed and extract was administered orally at a dose of 100 , 200, 400, 800, 1600, 3200, 6400 and 12,800 mg/kg. After the administration of test substance, food for the mice was withheld for $2 \mathrm{~h}$. Group I was given distilled water $(10 \mathrm{ml} / \mathrm{kg})$ as control [46].

\section{Observation period}

Animals were observed individually after atleast once during the first $30 \mathrm{~min}$, periodically during the first $24 \mathrm{~h}$, with special attention given during the first $4 \mathrm{~h}$, and daily thereafter, for a total of 14 days. All the mice were observed at least twice daily with the purpose of recording any symptoms of toxicity, survival or behavioural changes [46].

\section{Antitumor activity of $B$. variegata in subcutaneous melanoma B16F10-bearing mice Cell culture}

B16F10 melanoma tumor cell line was purchased from the National Centre for Cell Science (NCCS, Pune, India). The cells were maintained in RPMI 1640 medium buffered with
$2 \mathrm{~g} / \mathrm{l}$ of HEPES and sodium bicarbonate, and supplemented with dextrose, penicillin, streptomycin and 10\% of fetal bovine serum. The cells were maintained in a humidified atmosphere containing $5 \% \mathrm{CO}_{2}$ at $37{ }^{\circ} \mathrm{C}$. When needed for experiments the cells were harvested with trypsin: EDTA $(0.05: 0.03[w / v])$ solution, and then washed in phosphatebuffered saline (PBS, pH 7.4). For the animal experiments, the recovered cells were adjusted to $5 \times 10^{5}$ cells $/ \mathrm{ml}$ in PBS and then $200 \mu \mathrm{l}$ of the suspension was injected subcutaneously (S.C.) into dorsal side of C57BL/6 mice. After 810 days of injection, the tumor was found to develop into a budding state. When the tumor was developed to a palpable level, two doses of the plant extracts (leaf, stem bark and floral bud) at 500 and $750 \mathrm{mg} / \mathrm{kg} \mathrm{b}$. wt. of mice were given orally and cyclophosphamide at $170 \mathrm{mg} / \mathrm{kg}$ was injected intraperitoneally (i.p.) every alternate day up to 40 days. During the treatment, the size of implanted tumor [Fig. 4a] was regularly measured at given time interval, with a digital caliper and tumor volume was calculated [47].

\section{Experimental design}

A total of 72 adult male C57BL mice aged 6-8 weeks were divided into 12 groups thus each group containing 6 animals (Fig. 1).

Group NC: receiving normal saline $(10 \mathrm{~mL} / \mathrm{kg}$ b. wt.) treated as Normal Control.

Group TC: (tumor-bearing mice) receiving normal saline $(10 \mathrm{~mL} / \mathrm{kg})$ treated as Tumor Control.

Group CP: served as standard, which received cyclophosphamide (CP) $170 \mathrm{mg} / \mathrm{kg}$ b.wt.(tumor-bearing mice).

Group $L_{1}$ and $L_{2}$ (tumor bearing) Animals were received 500 and $750 \mathrm{mg} / \mathrm{kg}$ b.wt. B. variegata leaf extracts, respectively and after $30 \mathrm{~min}$ of $B$. variegata treatment, animals were treated with $\mathrm{CP}(170 \mathrm{mg} / \mathrm{kg}$ b.wt $)$

Group $\mathbf{L}_{3}$ : Animals were received orally with $500 \mathrm{mg} / \mathrm{kg}$ body weight of $B$. variegata leaf extract (tumor-bearing mice).

Group $_{1}$ and $\mathbf{B}_{\mathbf{2}}$ (tumor-bearing mice): Animals were received 500 and $750 \mathrm{mg} / \mathrm{kg}$ b.wt. B. variegata stem bark extracts, respectively and after $30 \mathrm{~min}$ of $B$. variegata treatment, animals were treated with $\mathrm{CP}(170 \mathrm{mg} / \mathrm{kg}$ b.wt $)$

Group $\mathbf{B}_{3}$ (tumor-bearing mice): Animals were received orally with $500 \mathrm{mg} / \mathrm{kg}$ body weight of $B$. variegata stem bark extract.

Group $F_{1}$ and $F_{2}$ (tumor-bearing mice): Animals were received 500 and $750 \mathrm{mg} / \mathrm{kg}$ b.wt. B. variegata floral bud extracts, respectively and after $30 \mathrm{~min}$ of $B$. variegata treatment, animals were treated with $\mathrm{CP}(170 \mathrm{mg} / \mathrm{kg}$ b.wt $)$

Group $F_{3}$ (tumor-bearing mice): Animals were received orally with $500 \mathrm{mg} / \mathrm{kg}$ body weight of $B$. variegata floral bud extract alone.

All treatment of B.variegata extract (leaf, stem bark, floral bud) was administered orally through a metal oropharyngeal cannula and Cyclophosphamide and normal saline were given intraperitoneally (i.p.) by $1 \mathrm{ml}$ syringe. 


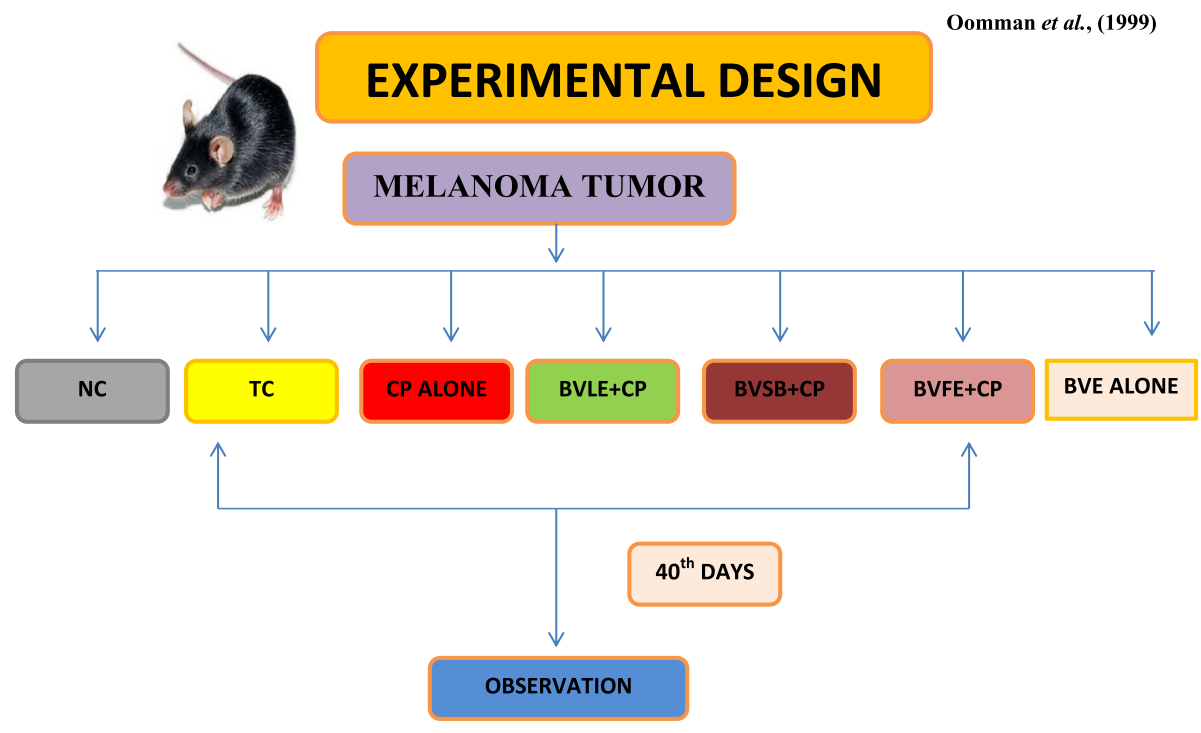

NC: Normal control (without Tumour bearing) (Normal saline $10 \mathrm{ml} / \mathrm{kg}$ bwt)

TC: Tumour control (Normal saline $10 \mathrm{ml} / \mathrm{kg}$ bwt)

CP: Cyclophosphamide (170 mg/kg bwt)

BVLE: Bauhinia variegata leaf extract

$500,750 \mathrm{mg} / \mathrm{kg}$ bwt

BVSB: Bauhinia variegata stem bark

BVFE: Bauhinia variegata floral extract

Route of administration: Oral

Fig. 1 Showing the Graphic representation of Different Groups for Bauhinia variegata leaf, stem bark and flower extracts with and without Cyclophosphamide on C57BL/6 mice

Whereas: NC: Normal control; TC: Tumour control; CP: Cyclophosphamide; L1, L2 and L3: Bauhinia variegata leaf extract; B1, B2 and B3: Bauhinia variegata Bark extract; F1, F2 and F3: Bauhinia variegata flower extract, i.p.: intraperitoneally

The tumour response was assessed by the tumour growth kinetics:

\section{Tumor Regression Studies [48, 49].}

Tumour Volume: During the treatment, the size of the implanted tumors was measured using Vernier calipers. Tumor volume was calculated by the following formula:

\section{Tumor volume $=$ length $\mathrm{X}$ width $^{2} / 2$}

Volume Doubling Time: Time required for the tumor to attain double the treatment volume.
Inhibition Rate: Tumor growth inhibition (\%TGI) was determined twice weekly during the dosing period by the formula:

$$
\mathbf{\% T G I}=\left(1-\left\{\mathbf{T}_{\mathbf{t}} / \mathbf{T}_{\mathbf{0}} / \mathbf{C}_{\mathbf{t}} / \mathbf{C}_{\mathbf{0}}\right\} / \mathbf{1}-\left\{\mathbf{C}_{\mathbf{0}} / \mathbf{C}_{\mathbf{t}}\right\}\right) \mathbf{X} 100
$$

where $T_{t}=$ median tumor volume of treated at time $t$, $\mathrm{T}_{0}=$ median tumor volume of treated at time $0, \mathrm{C}_{\mathrm{t}}=$ median tumor volume of control at time $t$ and $C_{0}=$ median tumor volume of control at time 0 .

Tumor growth inhibition $>50 \%$ is considered meaningful.

\section{Study on increase in life span of melanoma tumor bearing C57BL/6 mice [50, 51]:}

Mean survival time and median survival time (MST) was also calculated. The tumour response was assessed on the basis of the percentage increase in life span (\%ILS). 


$$
\% \mathrm{ILS}=\left\{\frac{\text { MST of Treated Group }}{\text { MST of Control Group }}\right\}-1 \times 100
$$

whereas: MST $=$ Mean survival time, ILS = Increase Life Span

An enhancement of life by $25 \%$ or more over that of control was considered as effective antitumor response [51].

Antioxidant parameter was studied in all the groups at the time of termination of the experiment (i.e., after 41 days).

\section{Determination of glutathione (GSH) level}

Glutathione was evaluated by sacrificing all the experimental mice were on day 41 st by cervical dislocation and liver and Kidney was removed.

\section{Preparation of homogenates}

After collection of blood samples [52], the mice were sacrificed. Then the liver and Kidney was excised, rinsed in ice cold normal saline followed by ice cold $10 \% \mathrm{KCl}$ solution, blotted, dried and weighed. A 10\% $(w / v)$ homogenate was prepared in ice cold $\mathrm{KCl}$ solution and centrifuged at $1500 \mathrm{rpm}$ for $15 \mathrm{~min}$ at $4{ }^{\circ} \mathrm{C}$. The supernatant thus obtained was used for the estimation of glutathione (GSH) $[53,54]$ level were checked using respective kits (SigmaAldrich Co. LLC) according to manufacturer's instruction. Reduced glutathione was used as a standard to calculate $\mu$ mole GSH/100 g tissue.

\section{Histopathological studies}

After the completion of drug treatment (40 days), on the day $41^{\text {st }}$ mice were sacrificed by cervical dislocation. The tumor of three animals from each group was dissected out, fixed in $10 \%$ buffered formalin for $12 \mathrm{~h}$ and processed for histopathological examination. $4 \mu \mathrm{m}$-thick paraffin sections were cut and stained with hematoxylin and eosin and mounted in DPX (used as a synthetic resin mounting media). Sections were qualitatively assessed under the light microscope for their architecture [55].

\section{Statistical analysis}

Results of Statistical analysis are presented as Mean \pm S.D. Statistical evaluation of data was performed by using one-way analysis of variance (ANOVA) followed by Dunnett's multiple comparison test. $P \leq 0.05$ was considered statistically significant.

\section{Results}

\section{Acute oral toxicity testing}

The present study conducted as per the OECD guidelines 423 revealed that an acute toxicity test in which no death occurred in more than one of the six animals given a dose of $2000 \mathrm{mg} / \mathrm{kg}$, the $\mathrm{LD}_{50}$ value can be considered greater than $2000 \mathrm{mg} / \mathrm{kg}$ and less than $5000 \mathrm{mg} / \mathrm{kg}$. In $\mathrm{LD}_{50}$ studies it were found that the different parts of B. variegata extract (leaf, stem bark and floral bud) did not produce any signs of toxicity or mortality up to the dose level $5000 \mathrm{mg} / \mathrm{kg}$ b.wt. Hence, the drug was considered to be safe up to the dose level of $2000 \mathrm{mg}$ per $\mathrm{kg}$ bwt.

\section{Effect of $B$. variegata in subcutaneous melanoma B16F10-bearing mice}

The study of tumor volume of mice shown in Fig. 2a revealed that in the groups $\left(\mathrm{L}_{3}, \mathrm{~B}_{3}\right.$, and $\left.\mathrm{F}_{3}\right)$ which received hydromethanolic extract of different parts of $B$. variegata (leaf, stem bark, floral bud) at 500 and $750 \mathrm{mg} / \mathrm{kg}$, b. wt. a reduction in the tumor volume was observed. On the day 40th of treatment, the reduction in the tumor volume was found to be significant $(P<0.05)$ for both the doses compared to tumor control group (TC), which received normal saline, $10 \mathrm{~mL} / \mathrm{kg}$, b.wt and Cyclophosphamide alone group $(\mathrm{CP})$.

When hydromethanolic leaf extract of $B$. variegata at 500 and $750 \mathrm{mg} / \mathrm{kg}$ was used as an adjuvant to chemotherapy groups $\left(\mathrm{L}_{1}\right.$ and $\left.\mathrm{L}_{2}\right)$ receiving cyclophosphamide at $170 \mathrm{mg} / \mathrm{kg}$, there was a statistically significant $(P<0.05)$ reduction in tumor volume on 40th day of tumor induction as compared to tumor control and cyclophosphamide alone group $\left(A_{1}\right.$ and $\left.A_{2}\right)$ as well as test drug group $\left(L_{3}\right)$. Simultaneously, $B$. variegata bark extract $\left(\mathrm{B}_{1}, \mathrm{~B}_{2}\right)$ and flower extract $\left(\mathrm{F}_{1}\right.$ and $\left.\mathrm{F}_{2}\right)$ at the dose of $500 \mathrm{mg} / \mathrm{kg}$ and $750 \mathrm{mg} / \mathrm{kg}$ with cyclophosphamide (CP) were also reduced tumor volume as compared to tumor control and cyclophosphamide group ( $\mathrm{NC}$ and $\mathrm{CP}$ ) as well as test drug alone group $\left(\mathrm{L}_{3} \mathrm{~B}_{3}\right.$ and $\left.\mathrm{F}_{3}\right)$ respectively.

The tumor doubling time (in days) Fig. $2 \mathrm{~b}$ of Cyclophosphamide group $(\mathrm{CP})$ was increased, whereas $B$. variegata leaf extract $(500 \mathrm{mg} / \mathrm{kg}$ and $750 \mathrm{mg} / \mathrm{kg})$ along with $\mathrm{CP}$ groups $\left(\mathrm{L}_{1}\right.$ and $\left.\mathrm{L}_{2}\right)$, tumor doubling time were reduced. Simultaneously, $B$. variegata bark $\left(\mathrm{B}_{1}\right.$ and $\left.\mathrm{B}_{2}\right)$ and flower extract $\left(F_{1}\right.$ and $\left.F_{2}\right)(500 \mathrm{mg} / \mathrm{kg}$ and $750 \mathrm{mg} / \mathrm{kg})$ along with $\mathrm{CP}$ groups were also reduced tumor doubling time respectively.

The inhibition rate Fig. 2c of B. variegata leaf extract alone $\left(\mathrm{L}_{3}\right)$ and cyclophosphamide group (CP) were decreased but when $B$. variegata leaf, stem bark, flower extract $\left(\mathrm{L}_{1}, \mathrm{~L}_{2}, \mathrm{~B}_{1}, \mathrm{~B}_{2}, \mathrm{~F}_{1}\right.$ and $\left.\mathrm{F}_{2}\right)$ along with $\mathrm{CP}$ were given, the inhibition rate were increased in tumor bearing mice as compared to tumor control (TC) and cyclophosphamide group $(\mathrm{CP})$ as well as test drug alone group $\left(\mathrm{L}_{3}, \mathrm{~B}_{3}\right.$ and $\left.\mathrm{C}_{3}\right)$ respectively.

The life span Fig. 2d was also increased in B. variegata leaf extract $(500 \mathrm{mg} / \mathrm{kg}$ and $750 \mathrm{mg} / \mathrm{kg}$ ) along with $\mathrm{CP}$ group $\left(\mathrm{L}_{1}\right.$ and $\left.\mathrm{L}_{2}\right)$, at the same time the $B$. variegata bark $\left(B_{1}\right.$ and $\left.B_{2}\right)$ and flower extract $\left(F_{1}\right.$ and $\left.F_{2}\right)$ along with cyclophosphamide group, life span were also increase in tumor bearing mice. The differences in the values of the results of experimental groups were statistically analyzed 

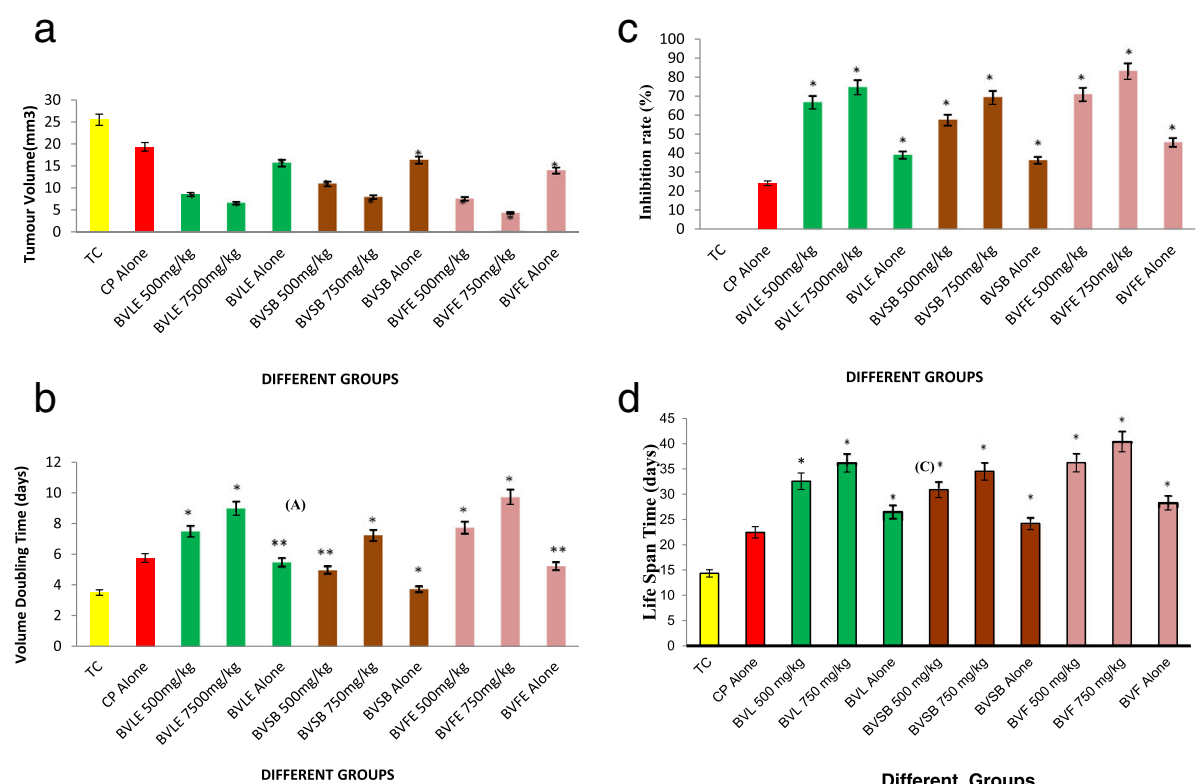

Fig. 2 Effect of Bauhinia variegata extract (leaf, stem bark, floral bud), individually or in combination with cyclophosphamide, on growth response of B16F10 melanoma tumour. a Changes in Tumour Volume of B16F10 tumour-bearing mice. The Tumour Volume was expressed in mili meter $\left(\mathrm{mm}^{3}\right) ; \mathbf{b}$ change in volume doubling time on the growth of induced melanoma tumour. The volume doubling time was expressed in days; c Inhibition Rate increase as per dose dependent manner; $\mathbf{d}$ Effect of Bauhinia variegata alone and single (low and high) dose of Bauhinia variegata extract along with CP as combination therapy, on the response of B16F10 Melanoma tumour bearing mice and mean survival time of C57BL/6 mice. The data represented Means \pm S.E.M. $(n=6$ mice) from triplicate experiments. **Significantly different from Tumour control group (TC) $(P<0.05)$. ${ }^{*}$ Significantly different from Cyclophosphamide group (CP) $(P<0.05)$. BVLE: Bauhinia variegata leaf extract; BVSB: Bauhinia variegata stem bark; BVF: Bauhinia variegata floral extract; CP: cyclophosphamide; TC: Tumour control; SEM: Standard error of mean

and found to be significant as compared to the tumor control group $(p<0.05)$.

Overall study revealed that the hydromethanolic extract of $B$. variegata floral buds exhibited stronger antitumor effect against melanoma tumor as compared to leaf extracts and stem bark extract.

\section{Determination of glutathione (GSH) level from non- tumor-bearing and B16-F10 melanoma-bearing mice}

The down regulation level of reduced glutathione in blood, liver and kidney of experimental mice were investigated to determine the antioxidative effect of test groups against the oxidative stress induced by melanoma cells. After induction of B16F10 mice melanoma cells, the level of glutathione (GSH) of blood, liver and kidney tissues of experimental mice were recorded. The percentage change on level of glutathione (GSH) per mg protein as a function of $B$. variegata alone or in combination with cyclophosphamide has been observed.

In the groups $\mathrm{L}_{1}, \mathrm{~L}_{2}, \mathrm{~B}_{1}, \mathrm{~B}_{2}, \mathrm{~F}_{1}$ and $\mathrm{F}_{2}$ which received in B. variegata extracts at 500 and $750 \mathrm{mg} / \mathrm{kg}$ b.wt. from the day of tumor initiation, the activities of glutathione (GSH) were much closer to normal control group (NC). Decreased concentration of reduced glutathione (GSH) in tumor control group has been observed compared to normal control. The percentage change on level of glutathione (GSH) per mg protein as a function of $B$. variegata alone or in combination with cyclophosphamide has been presented in Fig. 3.

Antioxidant enzymes activities of glutathione (GSH) (units $\mathrm{mg} /$ protein) in the liver and kidney homogenate and blood (ml/protein) were significantly increase $(P<0.05)$ in $B$. variegata extract along with cyclophosphamide treated groups $\left(\mathrm{L}_{1}, \mathrm{~L}_{2}\right)$ as compared to tumor control (TC) and cyclophosphamide alone group (CP) Fig. 3.

Subcutaneous induction of B16F10 melanoma showed a significant lowering of reduced glutathione in blood, liver and kidney (characteristic of antioxidants) compared to normal control group (NC) and reduced the scavenging of reactive oxygen species. A similar results wereobserved in stem bark and floral bud extracts Fig. 3a b and c.

B. variegata floral bud extracts exhibited stronger antioxidant activity as compared to leaf and stem bark extract. Among the groups studied, optimum value of reduced GSH per mg protein is found to be in the order, floral bud $>$ leaf $>$ stem bark > cyclophosphamide. Based on our observation, B. variegata floral extract exhibited optimum antioxidant activity and rendered significant protection against oxidative stress induced by melanoma in blood, liver and kidney tissues. 
a

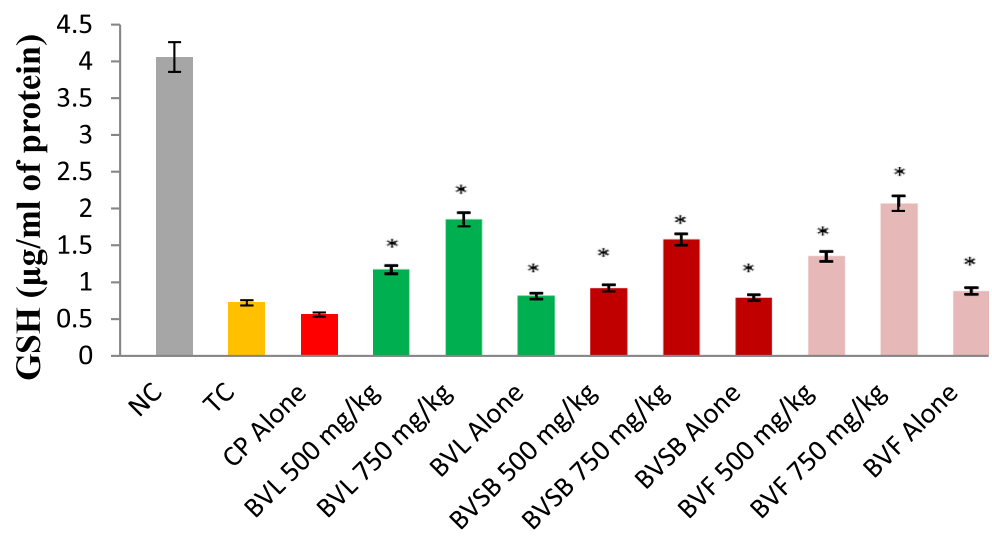

b

Different Groups

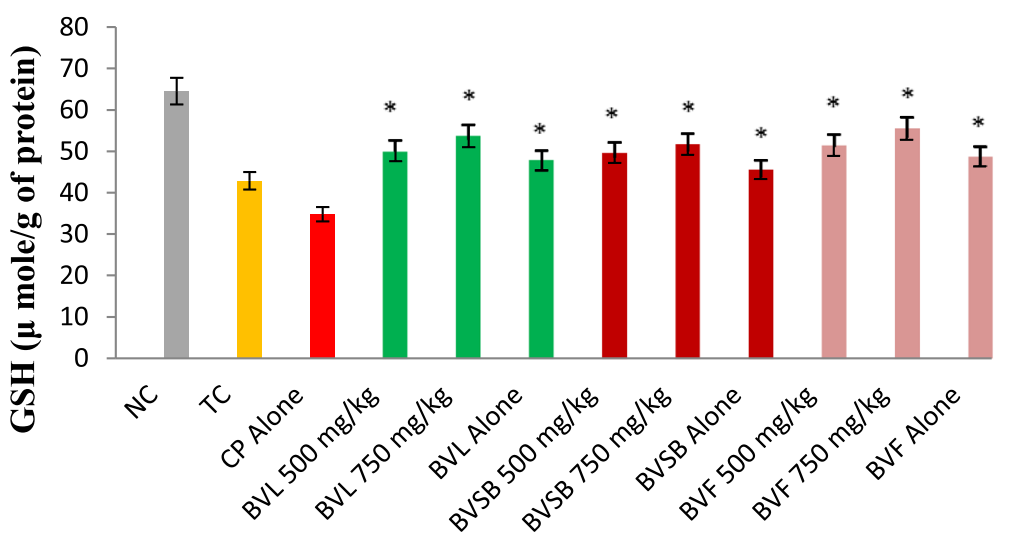

Different Groups

C

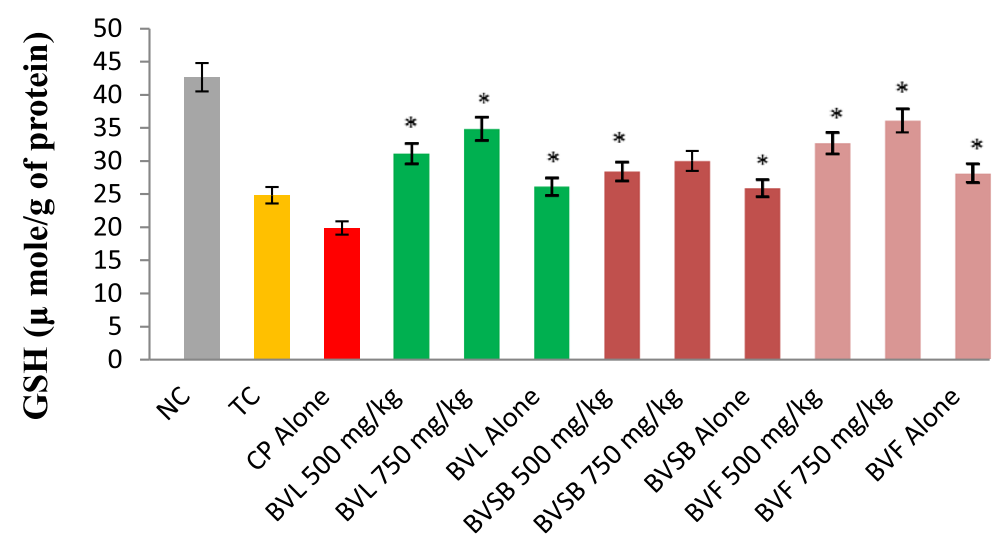

Different Groups

Fig. 3 Variations in the reduced glutathione (GSH) level in the liver, blood, kidney of mice during melanoma tumor with/with treatment of $B$. variegata extract. The Tumour GSH was expressed in $\mu$ mole/ml of protein in Blood (a); where as in Liver (b) and Kidney (c) expressed by $\mu$ mole/ $\mathrm{g}$ of protein. The data represented Means \pm S.E.M. ( $N=6$ mice) from triplicate experiments. * ${ }^{*}$ ignificantly different from cyclophosphamide group $(C P)$ and Tumour control (TC) group ( $p<0.05)$. BVLE: Bauhinia variegata leaf extract; BVSB: Bauhinia variegata stem bark; BVF: Bauhinia variegata floral extract; CP: cyclophosphamide; TC: Tumour control; SEM: Standard error of mean 


\section{Histopathology}

We have evaluated the efficacy of $B$. variegata on B16F10 mice melanoma tumors implanted subcutaneously in C57BL mice. Representative H\&E-stained sections of Tumor tissues recovered from the mice are shown in Fig. 4. The observation for histopathology was made on blood vessels, tumor cells, area of tumor regression, apoptosis and reduction in tumor mass. Histology of the tumor control group (TC) revealed the presence of hypervascularization where the perimeter of blood vessels large with the presence of hyperchromic tumor cells as compared to normal control (NC) group.
The apoptosis and dysplastic cells were significantly higher in tumors treated with group $\mathrm{CP}$ and tumor control group (TC). The groups (L, B, and F), treated with extracts of Bauhinia variegata at a dose of 500 and $750 \mathrm{mg} / \mathrm{kg}$, body weight revealed the presence of less live tumor cells with apoptosis as compared of tumor control group (TC) and Cyclophosphamide group (CP).

Analysis of the melanoma tumor sections on groups $\left(\mathrm{L}_{1}\right.$ and $\mathrm{L}_{2}$ ) which received extracts of Bauhinia variegata leaf along with cyclophosphamide at 500 and $750 \mathrm{mg} / \mathrm{kg}$, body weight from the day of tumor induction showed a progressive increase of apoptotic cells and perimeter of blood

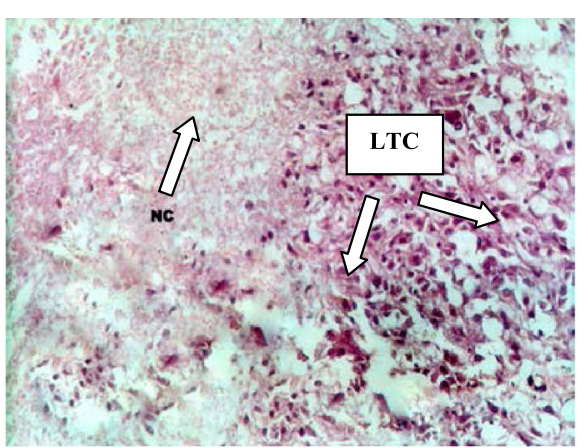

a

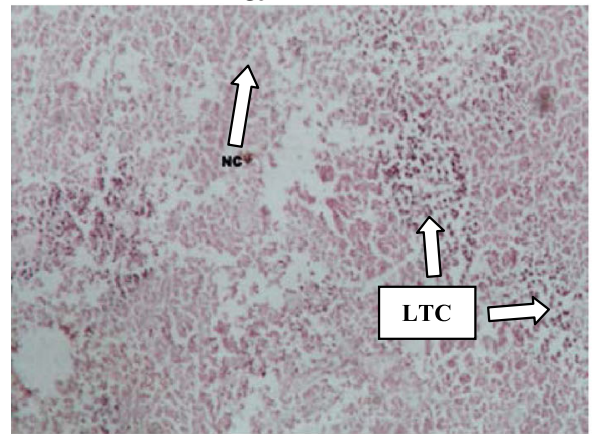

C

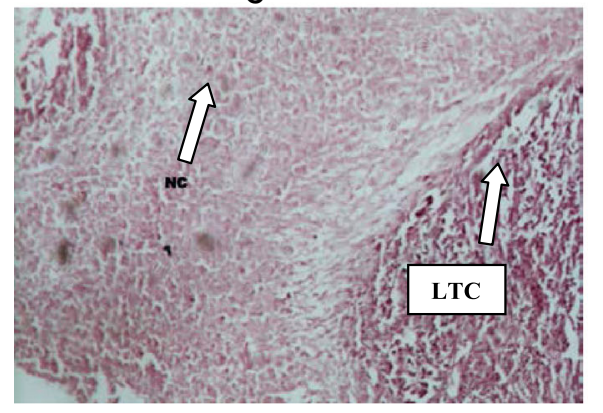

e

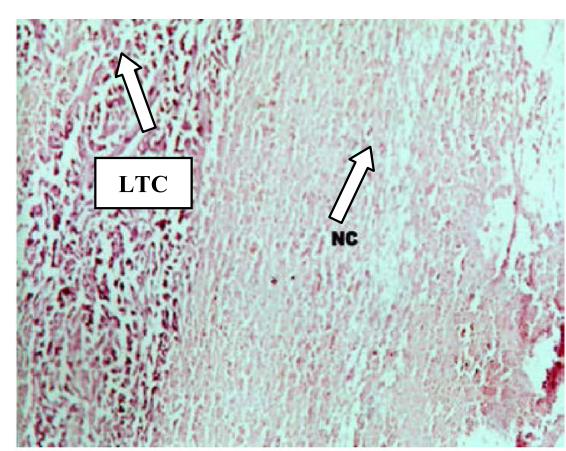

b

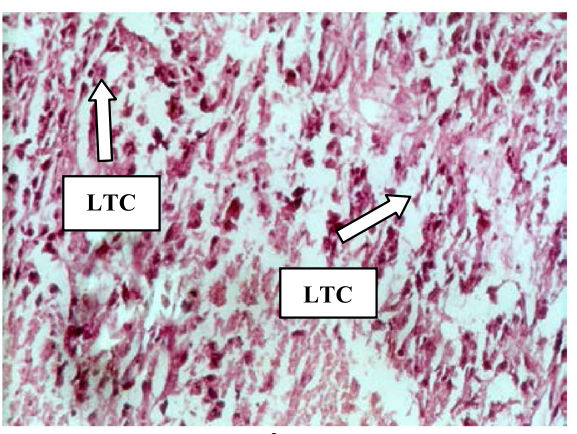

d

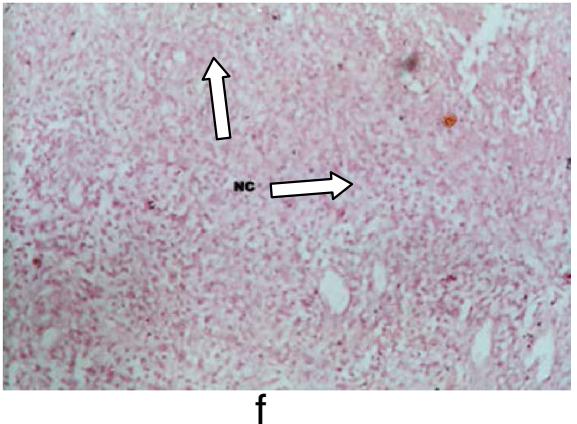

Fig. 4 Histopathology of melanoma tumor bearing C57BL/6 mice were subcutaneously transplanted with B16F10 cell line. A portion of excised tumor tissue from melanoma tumor bearing mice were fixed in 10\% formalin, cut into 5 - $\mu$ m thickness, stained using H\&E (hematoxylin and eosin) and then examined for histopathological changes. a The group which received cyclophosphamide (Positive control) showed equal quantity of both necrotic cells and tumor live cells but when the (b) Tumor bearing animals treated with $B$. variegata extract shows reduction in the live tumor cells and tumor mass; B. variegata (leaf, stem bark and flower) extract was given along with/without cyclophosphamide showed some histological changes such as (c) full necrosis with focal area of live cells, d Melanoma tumor suggests that total live tumor cells and (e) focal area of live cells with necrosis are present in the tumor control group (TC); (f) full necrosis and vivality with focal area of necrosis. Whereas: LTC - live Tumor cells, NC - Necrotic Cells 
vessels and vascular supply was less. A similar result was observed in stem bark and floral bud extracts also. The incidence of dysplastic cells and apoptosis in the tumor almost corresponded to the effect of tumor growth inhibition, suggesting that treatment resulted in tumor regression by significant augmentation of apoptosis. However, flower extract of $B$. variegata were found more effective as compared to leaf and stem bark extract.

\section{Discussion}

Cancer is a growing health problem worldwide, with the introduction of 6 million new cases every year. Many approaches are being tried through modulation of antitumor immune response, apoptosis, and antitumor proteins for cancer treatment [56]. Cancer cells lack the growth control of normal cells, exhibiting unlimited selfsufficient replication [57, 58]. For therapeutic effectiveness, drugs are being developed that act as biological modifiers, regulating the cell cycle and promoting cell death [59]. Plant derived compounds have been reported to induce cell cycle arrest and cell death in many tumor cell lines [60-65].

In recent years, the cancer rate has increased, especially in less developed countries. Identification and development of new chemotherapy drugs has been critical for cancer treatment. Plants have been a rich source of natural drugs [66, 67]. In addition, compounds derived from plants are diverse in structure and bioactivity and exhibit low toxicity, therefore they play an important role in pharmaceutical research [68]. In cancer therapy, many plant-derived drugs such as vincristine, paclitaxel and taxol have been identified and developed. Several works on epidemiology and animal model studies demonstrated that natural compounds, which possess antioxidant or anti-inflammatory properties, could inhibit carcinogenesis [69-72].

According to the traditional recommendations and experimental studies, numerous medicinal plants have been reported to have anticancer effect. Also antiproliferative, pro-apoptotic, anti-metastatic and anti-angiogenic effects of several phytochemicals have been shown in in vitro experiments or animal studies. However, only a small number have been tested in cancerous patients and limited evidence exists for their clinical effectiveness [73].

In the current study, we have selected $B$. variegata extracts to treat the melanoma tumor. The mice were treated with $B$. variegata extracts (stem bark, leaf and floral bud) at a dose of 500 and $750 \mathrm{mg} / \mathrm{kg}$, body weight. In the control group receiving normal saline, initially, a slow and steady growth in tumor volume was observed with a drastic increase in tumor size after few days.

Experimental tumor models are a critical pre-clinical step for the development and evaluation of chemotherapy regimens for cancer. Interestingly, we report here that the differential cytotoxic effect of these extracts was related not only to their chemical composition but may be also due to the nature of the tumor cells. In the present finding, the cancer treatment through chemotherapy with the combination of $B$. variegata was found more effective as compared to the extract alone. Earlier studies on herbs were reported that in cancer therapy many drugs when given alone give good results, however, when combined with other drugs exerting synergistic effect, the results are better. The objective of such approach is to minimize drug resistance and drug toxicity.

The B. variegata leaf, stem bark and flower extracts were studied on the inhibition of B16F10 melanoma tumor bearing mice. Study with the melanoma tumour model showed the effect of cyclophosphamide alone, $B$. variegata leaf, stem bark and flower extract (500 and $750 \mathrm{mg} / \mathrm{kg}$ body weight) along with Cyclophosphamide and $B$. variegata leaf, stem bark and flower extract alone groups. These were significantly reduced tumor volume and also increase survival time, inhibition rate and reduction of tumor doubling time in all B. variegata leaf, stem bark and flower extract as compare to tumour control (TC) and cyclophosphamide (CP) groups. Interestingly, I report here that the differential antitumor effect of these extracts was related not only to their chemical composition but may be also due to the nature of the tumor cells. Recent researches confirm the utility of herbs to both control cancer growth and to reduce side effects of chemotherapy. In addition, some herbs can reverse multidrug resistance [74].

A majority of the carcinogenic agents are regarded as powerful generators of free radicals leading to cancer. The reduction in tumor count may be due to effect in the promotional phase of tumourgenesis which prevent the reduction of free radicals [75].

Natural compounds have demonstrated strongest antioxidant and anticancer activity with multifunctional activity which also binds to and modulates activity of protein kinase involved in signal transduction cascades, show cytotoxic and cytostatic activity towards cancer cells [76]. The most quoted cancer prevention mechanism is via their activity, elicited either through direct free radical absorption or through induction od antioxidant enzymes such as superoxide dismutase (SOD), catalase and glutathione via a variety of molecular mechanisms [77, 78].

Glutathione (GSH) plays an important role in a multitude of cellular processes, including cell differentiation, proliferation, and apoptosis, and disturbances in GSH homeostasis are involved in the etiology and progression of many human diseases including cancer. While GSH deficiency, or a decrease in the GSH/glutathione disulphide (GSSG) ratio, leads to an increased susceptibility to oxidative stress implicated in the progression of cancer, elevated GSH levels increase the antioxidant capacity and the 
resistance to oxidative stress as observed in many cancer cells [79].

On the basis of the present study, it can be suggested that the $B$. variegata treated mice restores the changes in the activity of the antioxidant enzymes and the level of glutathione. Melanoma tumor group showed a sharp increase level of GSH in liver, kidney and Blood at B. variegata extract treated groups. It was observed that tumor cells produced more peroxides when they proliferate actively after inoculation of tumor. This rise in peroxides indicated the occurrence of intensification of oxygen free radical production [80]. Antioxidant molecules, such as GSH and vitamin E and $\mathrm{C}$ as well as antioxidant enzymes such as SOD, Catalase and glutathione peroxidase, have been long believed to have protective and anticancer activities by scavenging excess of free radicals. The liver is the main source of circulating plasma GSH (over $90 \%$ of the total GSH inflow) [81, 82]. As compared with non-tumorbearing mice, GSH levels decrease in the brain, lung, liver, and kidney of B16-F10-bearing mice [83].

In the current study, B. variegata therapy restored the antioxidant levels and increases the GSH content in tumor animals which may be due to the antioxidant and free radicles scavenging ability of the plant. Many studies reported that plant derived extracts containing antioxidant principles showed cytotoxicity towards tumor cells and antitumor activity in experimental animals [84].

Accumulating evidences [85-88] demonstrate that tumor growth and lethality are dependent on angiogenesis. An observation of histological slides (Fig. 4) exhibits the decrease in tumor growth in mice by the $B$. variegata extract which may be attributed to decreased host angiogenesis. B. variegata (leaf, stem bark and flower) extract along with/without cyclophosphamide groups showed some histological changes such as full necrosis, necrosis with focal area of live cells and vivality with focal area of necrosis, in C57BL/6 mice. A marked and dense microvasculature was observed in the tumor control group.

Preclinical animal models have been used extensively in the efficacy testing of potential chemopreventive agents. Standardized statistical methodology has been established to evaluate and compare the data from most of these animal model experiments based on the various endpoints [89]. A wide variety of naturally occurring substances have been shown to inhibit chemical carcinogenesis in animal models [90-92]. Nowadays, chemoprevention has been an important approach to control the process of cancer induction. Therefore, there is a need for exploring medicinal plants or other natural agents that can work as chemopreventive agents. The present study demonstrates the chemopreventive potential of $B$. variegata (leaf, stem bark and flower) extract on B16F10 melanoma tumour model in C57BL mice. The results of the present studies indicate that $B$. variegata (leaf, stem bark and flower) extract is effective as anticarcinogenic agent. Our observation agrees with the previous results of antitumor activity of the ethanolic extract of B. variegata extract against Dalton's ascetic lymphoma (DAL) in Swiss albino mice [93] and in N-notrosodiethylamine induced experimental liver tumour in rats and human cancer cell lines [94]. Our findings are also in agreement with the previous results of many herbal drugs such as alcoholic extract of Thuja occidentalis [95], aqueousmethanol (3:7) extract of Boerhaavia diffusa [96], methanolic extract of Withania somnifera roots [97], naturally occurring allyl and phenyl isothiocyanates [98], curcumin [99], sulphorafane [100], B. variegata leaf extract [101], Piper longum against A549 cell line [102], Cinnamaldehyde and eugenol [103] etc. have been reported to inhibit metastasis.

A numbers of drugs are used in cancer chemo and radiotherapy, and most of them exhibit cell toxicity and can induce genotoxic, carcinogenic, and teratogenic effects in non-tumor cells [104]. These side effects limit the use of conventional chemotherapeutic agents despite their high efficacy in treating cancerous cells. Therefore, the search for alternative drugs/molecules that are effective and non-toxic in the treatment of cancers is an important research area [105]. In fact, sincere efforts are being made to isolate bio-actives from medicinal plants for their potential in cancer treatment [106].

There is emerging scientific evidence of herbal medicines playing an important role in the supportive care of cancer therapy [107]. Herbal extract have flavonoids, anthraquinones, and saponins which might be responsible for exhibiting anticancer effect. There are some literatures which have reported biological interactions of flavonoids, polyphenols, or phenolic compounds with proteins, enzymes, and other biological processes in the cells that make them toxic to the tumour cell or serve as growth inhibitors for cancer cells [108].

Moreover, flavonoids have an anti-proliferative role in cancer through their effects on signal transduction in cell proliferation and angiogenesis [109, 110]. Study has been reported that presence of secondary metabolites such as terpenoids, phenolics, flavonoids, anthraquinones, saponins, tannins, and alkaloids in B. variegata leaf, stem bark and floral bud extracts [32, 111].

Prevention and cure of diseases using phytochemicals especially flavonoids are well known. Variety of flavonoids found in the nature possesses their own physical, chemical, and physiological properties. Structure function relationship of flavonoids is epitome of major biological activities. Medicinal efficacy of many flavonoids as antibacterial, hepatoprotective, anti-inflammatory, anticancer, and antiviral agents is well established. These substances are more commonly used in the developing countries. Many flavonoids are shown to have antioxidative activity, 
free radical scavenging capacity, coronary heart disease prevention, hepatoprotective, anti-inflammatory, and anticancer activities [112].

Studies have been reported that several naturally occurring compounds exhibited antitumor promoting activity in B16F10 melanoma tumour model. Solanum lycopersicum fruit extracts has reported to inhibit the B16F10 melanoma tumour in C57BL mice [113] and Lawsonia inermis leaf extract has also been reported to possess anticarcinogenic property against B16F10 melanoma tumour model [114]. Bauhinia variegata flower extract has been reported to show Chemopreventive activity against DMBA-induced skin Papillomagenesis in mice [115]. The Withania somniferaand its bioactive fraction Withanolide D were studied for their anti-metastatic activity using B16F10 melanoma cells in C57BL/6 mice. Keishi-ka-kei-to is a traditional Chinese herbal medicine which is reported to inhibit pulmonary metastasis in mice bearing B16F10 melanoma cells through the stimulation of CD8+ T cells [116].

The mechanism of tumor growth reduction in vivo induced by $B$. variegata seems to involve apoptosis induction. Presently, I have shown that the hydrometholic extract of B. variegata have flavonoid compounds. Finally, the isolation of the active principles of the hydromethanolic extract of $B$. variegata is currently being undertaken to investigate their cytotoxic, molecular and genetic action mechanisms, which could provide meaningful perspectives for biomedical and future drug development research.

\section{Conclusion}

Tumors employ multiple mechanisms for their uncontrolled proliferation, invasion, angiogenesis and metastasis. It is therefore logical to envision that a combination of approaches that target different mechanisms will be more effective at inhibiting tumor growth or destroying tumors than a single agent approach. As mentioned in the preceding section, few of the researches on tumor and angiogenesis have been reported using different plants in an animal model other than melanoma tumor model (study model of the present research work). The rapid increase in utilization of herbal remedies worldwide has been inspired by several factors, including the concept that herbal products are safe and effective and so investigation on medicinal plants is increasing day by day.

In conclusion, the present piece of in vivo experiments highlight the effectiveness of $B$. variegata combination among all the treatment studied and is found capable for reducing melanoma against reference drug cyclophosphamide. Oral administration of B. variegata extract simultaneously with tumor inoculation showed significant reduction in the tumor volume. The extract treatment also produced significant increase in the life span of tumor bearing C57BL/6 mice as compared to cyclophosphamide alone and Tumor control groups. The activity of B. variegata was found in following order floral bud $>$ leaf extract $>$ stem bark extract. Further, the antitumor activity of $B$. variegata in mice may be attributed to the presence of polar phytoconstituents such as alkaloids, flavonoids, tannins, terpenoids, and glycosides present in the crude extract of $B$. variegata. The endeavor of the present study was to travel around the potential anti-tumor activity of $B$. variegata extract on melanoma tumor. The study was not only supportive in determining the optimum dose extract employed against melanoma tumors but also in the development of a new and a potential anti-cancer drug. The hydromethanolic extract of $B$. variegata is an effective and potent antitumor agent against human malenoma so it may provide a poor man friendly and a drug of preference to the world. The use of new agents in clinical phases needs more investigations on its the molecular mechanism of action and potential usefulness of $B$. variegata as an agent for cancer therapy.

\section{Abbreviations}

b.wt:: Body weight; B16-F10: B16 melanoma F10 subline; BVFE: Bauhinia variegata Flower Extract; BVLE: Bauhinia variegata Leaf Extract; BVSE: Bauhinia variegata Stem bark Extract; CYP: Cyclophosphamide; GSH: Glutathione; H\&E: Haemotoxylin and Eosin; I.P: Intraperitoneal; ILS: Increase in life span; IR: Inhibition rate; LTC: live Tumor cells; MST: Mean survival time; NC: Necrotic Cells; PBS: Phosphate Buffer Saline; SC: Subcutaneous; VDT: Volume doubling time

\section{Acknowledgements}

The authors are thankful to Dr. R.C. Agrawal (Guide) and Shri Madan Mohan Joshi, chairman of the Jawaharlal Nehru Cancer Hospital and Research Centre, Bhopal for providing facilities to carry out the present work.

\section{Funding}

There was no funding source for this study. This quality study was approved by the RDC (Research Degree Committee) of Barkatullah University, Bhopal, Madhya Pradesh India.

\section{Availability of data and materials}

The data sets during and/or analyzed during the current study available from the corresponding author on reasonable request.

\section{Authors' contributions}

SP carried out and supervised the molecular genetic studies, interpretation of data, participated in drafting the manuscript. Author read and approved the final manuscript

\section{Authors' information \\ Dr. Sonam Pandey obtained MSc (Microbiology) from Rani Durgavati University, Jabalpur, Madhya Pradesh, India and Ph.D (Bioscience) from Barkatullah University, Bhopal, Madhya Pradesh, India. She is currently working as Research Associate cum Project Coordinator (TRAE Cell) Gujarat State Biotechnology Mission, Gandhinagar, Gujarat, India. She has made contribution in the field of Toxicology, Carcinogenicity and evaluation of Herbal medicinal plants for the benefits of cancer patient. Her area of expertise includes Preclinical Pharmacology, Toxicology, Carcinogenicity, Mutagenicity, Histopathology, Microbiology, Biotechnology, and Biochemistry.}

Ethics approval and consent to participate

The study was approved by our institution internal Research Ethics Committee.

Project approval No: ProjectNo.43/Ref No. 670/225.IAE/2008

Consent for publication

I have consent form for this publication. 


\section{Competing interests}

The author declares that she has no competing interests.

\section{Publisher's Note}

Springer Nature remains neutral with regard to jurisdictional claims in published maps and institutional affiliations.

\section{Received: 23 February 2017 Accepted: 1 August 2017}

\section{Published online: 30 September 2017}

\section{References}

1. Jemal A, Siegel R, Ward E, Murray T, Xu J, Smigal C, Thun MJ. Cancer statistics, 2006. CA cancer J. Clin. 2006(56):106-30.

2. Balch CM, Soong SJ, Gershenwald JE, Thompson JF, Reintgen DS, Cascinelli N Urist M, McMasters KM, Ross Ml, Kirkwood JM, et al. Prognostic factors analysis of 17, 600 melanoma patients: validation of the American joint committee on cancer melanoma staging system. J Clin Oncol. 2001;19:3622-34.

3. Macdonald JS. Toxicity of 5-fluorouracil. Oncology. 1999;13(7 Suppl 3):33-4.

4. Rexroth G, Scotland V. Cardiac toxicity of 5-fluorouracil. Med Klin. 1994; 89(12):680-8.

5. Rastogi N, Chag M, Ayyagari S. Myocardial ischemia after 5-fluorouracil chemotherapy. Int J Cardiol. 1993:42(3):285-7.

6. Aviles A, Arevila N, Diaz Maqueo JC, Gomez T, Garcia R, Nambo MJ. Late cardiac toxicity of doxorubicin, epirubicin, and mitoxantrone therapy for Hodgkin's disease in adults. Leuk Lymphoma. 1993;11(3-4):275-9.

7. Leo E, Arletti R, Forni F, Cameroni R. General and cardiac toxicity of doxorubicin-loaded gelatin nanoparticles. Farmaco. 1997;52(6-7):385-8.

8. Kilickap S, Akgul E, Aksoy S, Aytemir K, Barista I. Doxorubicin-induced second degree and complete atrioventricular block. Europace. 2005;7(3):227-30.

9. Manil L, Couvreur P, Mahieu P. Acute renal toxicity of doxorubicin (adriamycin)loaded cyanoacrylate nanoparticles. Pharm Res. 1995;12(1):85-7.

10. Gibaud S, Andreux JP, Weingarten C, Renard M, Cou-vreur P. Increased bone marrow toxicity of doxorubicin bound to nanoparticles. Eur J Cancer. 1994;30A(6):820-6

11. Adamson IY. Pulmonary toxicity of bleomycin. Environ Health Perspect. 1976;16:119-25.

12. Parvinen LM, Kilkku P, Makinen E, Liukko P, Gronroos M. Factors affecting the pulmonary toxicity of bleomycin. Acta Radiol Oncol. 1983;22(6):417-21.

13. Karam H, Hurbain-Kosmath I, Housset B. Direct toxic effect of bleomycin on alveolar type 2 cells. Toxicol Lett. 1995;76(2):155-63.

14. Cohen IS, Mosher MB, O'Keefe EJ, Klaus SN, De Conti RC. Cutaneous toxicity of bleomycin therapy. Arch Dermatol. 1973;107(4):553-5.

15. Fraiser LH, Kanekal S, Kehrer JP. Cyclophosphamide toxicity. Characterising and avoiding the problem. Drugs. 1991:42(5):781-95.

16. Uma Devi P. Normal tissue protection in cancer therapy: progress and prospects. Acta Oncol. 1998:37:247.

17. Foster-Nora JA, Siden R. Amifostine for protection from antineoplastic drug toxicity. Am J Health Syst Pharm. 1997:54:787.

18. Uma Devi P, Ganasoundari A. Radioprotective effect of leaf extract of Indian medicinal plant Ocimum Sanctum. Indian J Exp Biol. 1995;33:205.

19. Goel HC, Prasad J, Sharma A, Singh B. Antitumor and radioprotective action of Podophyllum Hexandrum, Indian. J Exp Biol. 1998;36:585.

20. Uma Devi P, Ganasoundari A, Rao BSS, Srinivasam KK. In vivo radioprotection by Podophuyllum flavonoids: survival of mice. Radiat Res. 1999:515:74

21. Osawa T, Kawakishi S, Namiki M. In: Kuroda Y, Shankel, D M, Waters M D. Antimutagenesis and Anticarcinogenesis mechanism II. Newyork: plenum. p. 139-53

22. Di Carlo G, Mascolo N, Izzo AA, Capassao F. Flavonoids old and new aspects of a class of natural therapeutic drugs. Life Sci. 1999;65:337-53.

23. Keith MW, Sally AL, Michael WS, Thomas JG, Garry MM. Taxus Spp. needles contain amounts of tax oil comparable to the stem bark of taxus brevifolia: analysis and isolation. Nat Prod. 1990;53:1249-55.

24. Roja G, Heble MR. The quinoline alkaloid camptothecin from tissue cultures and mature trees of Nathapodytes foetida. Phytochemistry. 1994;36:65-6.

25. Fransworth NR, Akerele O, Bingel AS, Soejarto DD. And Guo. Z. Medicinal plants in therapy. Bull WHO. 1985;63:965-81.

26. Surh YJ. Molecular mechanisms of chemopreventive effects of selected dietary and medical phenolic substances. Mutat Res. 1999;428:305-27.

27. Mashele S, Fuku SL. Evaluation of the antimutagenic and mutagenic properties of Asparagus laricinus. Med Technol SA. 2011;25:33-6.
28. Youn MJ, Kim JK, Park SY, Kim Y, Park C, Kim ES. Potential anticance properties of the water extract of Inonotus obliquus by induction of apoptosis in melanoma B16-F10 cells. J Ethnopharmacol. 2009;121:221-8.

29. Park HJ, Han ES, Park DK. The ethyl acetate extract of PGP (Phellinus linteus grown on Panax ginseng) suppresses B16F10 melanoma cell proliferation through inducing cellular differentiation and apoptosis. J Ethnopharmacol. 2010;132:115 21.

30. Hu W, Zhang C, Fang Y, Lou C. Anticancer properties of 10hydroxycamptothecin in a murine melanoma pulmonary metastasis model in vitro and in vivo. Toxicol in Vitro. 2011;25:513-20.

31. Pandey S. Ethno-pharmacological review of Bauhinia variegata: a potential herbal drug. Res Rev: J Herb Sci. 2013;2(2):6-11.

32. Pandey S. Preliminary phytochemical screening and in vitro antibacterial activity of Bauhinia variegata Linn. Against human pathogens. Asian Pac J Trop Dis. 2015;5(2):123-9.

33. Gupta R, Paarakh MP, Gavani U. Isolation of Phytoconstituents from the leaves of Bauhinia variegata Linn. J Pharm Res. 2009:2(8):1315-6.

34. Kumar D, Parcha V, Maithani A, Dhulia I. Effect and evaluation of antihyperlipidemic activity of fractions of total methanol extract of Bauhinia variegata (Linn.) leaves on triton WR-1339 (Tyloxapol) induced hyperlipidemic rats. Int J Res Pharm Sci. 2011;2(4):493-7.

35. Vileges JH, DeMarchi E, Lancas EM. Phytochemical studies of some medicinal plants. Anal. 1997;8:266-70.

36. Gamble JS. Flora of the presidency of madras, vol. 2. Calcutta: Botanical Survey of India; 1956.

37. Gupta AK, Chauhan JS. Constituents from the stem of Bauhinia variegata. Natl Acad Sci Lett. 1984;7:15-6.

38. Gupta AK, Vidyapati TJ, Chauhan JS. 5, 7- Dihydroxyflavanone-4-O-Z-Lrhamnopyranosyl-e-glucopyranoside from Bauhinia variegata. Indian J Chem. 1979;18 B:85-6.

39. Sharma DD, Chawla MS, Negi SS. Chemical composition and nutritive value of Bamboo saarundinacea and Bauhinia variegata tree leaves. J Res pharm. 1968:5:253-8.

40. Singh RS. Pandey, HS, Ghanshyam.Two new long chain compounds from Bauhinia variegata Linn. Ind J Chem. 2006;45B:2151-3.

41. Hirano T, Oka K, Akiba M. Antiproliferative effect of synthetic and naturally occurring flavonoids on tumour cells of human carcinoma cells lines. Res Comm Chem, Pathol Pharmacol. 1989;64:69-78.

42. Rajkapoor B, Jayakar B, Murgesh N. Sub chronic toxicity of plant extract Bauhinia variegata on rats. J Ecotoxicol Env Monitor. 2004;14:71-4.

43. Rajkapoor B, Jayakar B, Murgeshand ND, Akthisekaran. Chemoprevention and cytotoxic effect of Bauhinia variegata against $\mathrm{N}$-nitrosodiethylamine induced liver tumors and human cancer cell lines. J Ethnopharmacol. 2006; 104:407-9.

44. Parekh J, Chanda S. In vitro antimicrobial activity of Trapa natans L. fruit rind extracted in different solvents. Afr. J. Biotechnol. 2007;6(16):1905-9.

45. Organization for Economic Co-operation and Development. OECD guideline for testing of chemicals. Acute oral toxicityacute toxic class method. OECD Guidelines for the Testing of Chemicals (No. 423). Health effects. 2010; 1(4): 1-14.

46. Ecobichon DJ. The basis of toxicology testing. New York: CRC Press; 1997. p. 43-86.

47. Uma Devi P, Kamath R, Rao BSS. Radiosensitization of a mouse melanoma by withaferin a: In vivo studies. Ind J Exp Biol. 2000;38:432-7.

48. Uma Devi P, Guruprashad K. Influence of clamping -induced ischemia and reperfusion on the response of a mouse melanoma to radiation and hyperthermia. Int J Hyperth. 2001;17(4):357-67.

49. Rajkapoor B, Jayakar B, Murugesh N. Antitumor activity of Indigofera aspalathoides on ehrlich ascites carcinoma in mice. Ind J Pharmacol. 2004;36(1):38-40.

50. Uma Devi P, Soloman FE, Shardra AC. In vivo tumor inhibitory and radiosensitizing effects of an Indian medicinal plant, Plumbago rosea on experimental mouse tumors. Ind J Exp Biol. 1994;32:523-8.

51. Geran Rl, Greenberg NH, Mac Donald MM, Schumacher AM, Abbot BJ. Cancer Chemother Rep. 1972;3:1

52. Beutler $\mathrm{E}$, Duron $\mathrm{O}$, Kellin BM. Improved method for the determination of blood glutathione. J Lab Clin Med. 1963;61:882-8.

53. Ellman GL. Tissue sulfhydryl groups. Arch Biochem Biophys. 1959:82:70-7.

54. Moron MS, Depiere JW, Mannervik B. Levels of GSH, GR and GST activities in rat lung and liver. Biochemica Biophysica Acta. 1979:582:67-78.

55. Krajian AA. Tissue cutting and staining. In: Frankel S, Reitman S, editors. Gradwohl's clinical laboratory methods and diagnosis. USA: The CV. Mosby Co. Saint Louis; 1963. p. 1639. 
56. Tascilar M, de Jong FA, Verweij J, Mathijssen RH. Complementary and alternative medicine during cancer treatment: beyond innocence. Oncologist. 2006;11:732-41.

57. Hartwell LH, Kastan MB. Cell cycle control and cancer. Science. 1994 266(5192):1821-8.

58. Vermeulen K, Van Bockstaele DR, Berneman ZN. The cell cycle: a review of regulation, deregulation and therapeutic targets in cancer. Cell Prolif. 2003; 36(3):131-49.

59. Zhang Y, Li Q, Ge Y, Chen Y, Chen J, Dong Y, et al. Silibinin triggers apoptosis and cell-cycle arrest of SGC7901 cells. Phytother Res. 2013;27(3): 397-403.

60. Kroemer G, Galluzzi L, Vandenabeele P, Abrams J, Alnemri ES, Baehrecke EH, et al. Classification of cell death: recommendations of the nomenclature committee on cell death 2009. Cell Death Differ. 2009;16(1):3-11.

61. Geethangili M, Rao YK, Fang SH, Tzeng YM. Cytotoxic constituents from Andrographis Paniculata induce cell cycle arrest in jurkat cells. Phytother Res. 2008;22(10):1336-41

62. Nadova S, Miadokova E, Mucaji P, Grancai D, Cipak L. Growth inhibitory effect of ethyl acetate-soluble fraction of Cynara Cardunculus L. in leukemia cells involves cell cycle arrest, cytochrome $c$ release and activation of caspases. Phytother Res. 2008:22(2):165-8.

63. Hosseini A, Ghorbani A. Cancer therapy with phytochemicals: evidence from clinical studies. Avicenna J Phytomed. 2015;5(2):84-97.

64. Du B, Zhong X, Liao X, Xu W, Zhou X, Xu S. A new antitumor arabinopyranoside from Laurencia Majuscula induces G2/M cell cycle arrest. Phytother Res. 2010;24(10):1447-50.

65. Kim SJ, Min HY, Lee EJ, Kim YS, Bae K, Kang SS, et al. Growth inhibition and cell cycle arrest in the G0/G1 by schizandrin, a dibenzocyclooctadiene lignan isolated from Schisandra Chinensis, on T47D human breast cancer cells. Phytother Res. 2010:24(2):193-7.

66. Lee EJ, Kim WJ, Moon SK. Cordycepin suppresses TNF-alpha-induced invasion, migration and matrix metalloproteinase-9 expression in human bladder cancer cells. Phytother Res. 2010;24(12):1755-1761. [PubMed].

67. Cragg GM, Newman DJ. Natural products: a continuing source of novel drug leads. Biochim Biophys Acta. 2013;1830(6):3670-95.

68. Newman DJ, Cragg GM. Natural products as sources of new drugs over the 30 years from 1981 to 2010. J Nat Prod. 2012;75(3):311-35.

69. Gali-Muhtasib H, Hmadi R, Kareh M, Tohme R, Darwiche N. Cell death mechanisms of plant-derived anticancer drugs: beyond apoptosis. Apoptosis. 2015:20(12):1531-62.

70. Rajakrishnan V, Shiney SJ, Sudhakaran PR, Menon VP. Effect of curcumin on ethanol-induced stress on mononuclear cells. Phytother Res. 2002;16(2):171-3.

71. Hanif R, Qiao L, Shiff SJ, Rigas B. Curcumin, a natural plant phenolic food additive, inhibits cell proliferation and induces cell cycle changes in colon adenocarcinoma cell lines by a prostaglandin-independent pathway. J Lab Clin Med. 1997:130(6):576-84

72. Jiang MC, Yang-Yen HF, Yen JJ, Lin JK. Curcumin induces apoptosis in immortalized NIH 3 T3 and malignant cancer cell lines. Nutr Cancer. 1996; 26(1):111-20.

73. Limtrakul P, Anuchapreeda S, Lipigorngoson S, Dunn FW. Inhibition of carcinogen induced c-ha-ras and c-fos proto-oncogenes expression by dietary curcumin. BMC Cancer. 2001;1(1):1.

74. Shu X, McCulloch M, Xiao H, Broffman M, Gao J. Chinese herbal medicine and chemotherapy in the treatment of hepatocellular carcinoma: a meta-analysis of randomized controlled trials. Integr Cancer Ther. 2005:4:219-29.

75. Wei H. Frenkel K. In vivo formation of oxidized DNA base in tumor promoter-treated mouse skin. Cancer Res. 1991;51(16):4443-9.

76. Colic M, Pavelic KJ. Molecular mechanisms of anticancer activity of natural dietetic products. Mol Med. 2000;78:333-6.

77. Reuland DJ, Khademi S, Castle CJ, et al. Upregulation of phase II enzymes through phytochemical activation of Nrf2 protects cardiomyocytes against oxidant stress. Free Radic Biol Med. 2013:56:102-11.

78. Johnson I. Phytochemicals and cancer. Proc Nutr Soc. 2007;66:207-15.

79. Nicola Traverso, Roberta Ricciarelli, Mariapaola Nitti, et al. "Role of Glutathione in Cancer Progression and Chemoresistance". Oxid Med Cell Longev. 2013;2013:10. Article ID 972913. doi:10.1155/2013/972913

80. Navarro J, Obrador E, Pellicer JA, Asensi M, Vina J, Estrela JM. Blood glutathione as an index of radiation-induced oxidative stress in mice and humans. Free Radic Biol Med. 1997;22:1203-9.
81. Meister A. Glutathione deficiency produced by inhibition of its synthesis, and its reversal; applications in research and therapy. Pharmacol Ther. 1991;51(2):155-94

82. Obrador E, Carretero J, Ortega A, Medina I, Rodilla V, Pellicer JA, Estrela JM. $\gamma$-Glutamyl transpeptidase overexpression increases metastatic growth of B16 melanoma cells in the mouse liver. Hepatol. 2002;35:74-81.

83. Griffith OW, Meister A. Glutathione: interorgan translocation, turnover, and metabolism Proc. Natl Acad Sci USA. 1979;76:5606-10.

84. Ruby AJ, Kuttan G, Dinesh Babu K, Rajasekharan KN, Kuttan R. Anti-tumor and antioxidant activity of natural curcuminoids. Cancer Lett. 1995;94:79-83.

85. Folkman J. Angiogenesis research: from laboratory to clinic. Forum (Genova). 1999;9(Suppl 3):59-62.

86. Saaristo A, Karpanen T, Alitalo K. Mechanisms of angiogenesis and their use in the inhibition of tumor growth and metastasis. Oncogene. 2000;19:6122-9.

87. Folkman J. Role of angiogenesis in tumor growth and metastasis. Semin Oncol. 2002;29:15-8

88. Chekenya M, Hjelstuen M, Enger PQ, Thorsen $\mathrm{F}$, Jacob AL, Probst $\mathrm{B}$, et al. The NG2 proteoglycan promotes angiogenesis dependent tumor growth in CNS by sequestering angiostatin. FASEB J. 2002;16:586-8.

89. Williams GW. Modulation of chemical carcinogenesis by xenobiotics. Fund Appl Toxicol. 2004:4:325-44.

90. Wattenberg LW. Chemoprevention of cancer. Cancer Res. 1985;45:1-8.

91. Unnikrishnan MC, Kuttan R. Tumor reducing and anticarcinogenic activity of selected spices. Cancer Lett. 1990;51:85.

92. Boone CW, Kelloff GJ, Malone WE. Identification of cancer chemotherapy agents and their evaluation in animal models and human clinical trials: a review. Cancer Res. 1990;50:2-9.

93. Rajkapoor B, Jayakar B, Murugesh N. Antitumour activity of Bauhinia variegata on Dalton's ascitic lymphoma. J Ethnopharmacol. 2003a;89(1):107-9.

94. Rajkapoor B, Jayakar B, Murgesh N, Sakthisekaran D. N-notrosodiethylamine induced experimental liver tumour in rats and human cancer cell lines. J Ethnopharmacol. 2006;104(3):407-9.

95. Sunila ES, Kuttan G. A preliminary study on antimetastatic activity of Thuja occidentalis L. in mice model. Immunopharmacol Immunotoxicol. 2006:28: 269-80.

96. Leyon PV, Lini CC, Kuttan G. Inhibitory effect of Boerhaavia diffusa on experimental metastasis by B16F10 melanoma in C57BL/6 mice. Life Sci. 2005:76:1339-49.

97. Leyon PV, Kuttan G. Effect of Withania somnifera on B16F-10 melanoma induced metastasis in mice. Phytother Res. 2004;18:118-22.

98. Manesh C, Kuttan G. Effect of naturally occurring allyl and phenyl isothiocyanates in inhibition of experimental pulmonary metastasis induced by B16F-10 melanoma cells. Fitoterapia. 2003;74:355-63.

99. Menon LG. Kuttan R, Kuttan G (1999). Anti-metastatic activity of curcumin and catechin. Cancer Lett. 1999:141:159-65.

100. Thejass P, Kuttan G. Anti-metastatic activity of sulphorafane. Life Sci. 2006:78:3043-50.

101. Sharma UK, Sharma AK, Pandey AK. Protective effect of Bauhinia Variegata leaf extracts against oxidative damage, cell proliferation and bacterial growth. Proc Natl Acad Sci India sect B biol Sci. 2017;87(1):45-51.

102. Sharma AK, Kumar S, Chashoo G, Saxena AK, Pandey AK. Cell cycle inhibitory activity of Piper longum against A549 cell line and its protective effect against metal-induced toxicity in rats. Ind J Biochem Biophys. 2017;51(5):358-64

103. Sharma U, Sharma AK, Pandey AK. Medicinal attributes of majo phenylpropanoids present in cinnamon. BMC Complement Altern Med. 2016;16:156.

104. Philip PA. Experience with docetaxel in the treatment of gastric cancer. Semin Oncol. 2005;32:S24-38.

105. Tang W, Hemm I, Bertram B. Recent development of antitumor agents from Chinese herbal medicines. Part II. High molecular compounds (3) Planta Med. 2003:69:193-201.103.

106. Kinghorn AD, Su BN, Jang DS, Chang LC, Lee D, Gu JQ. Natural inhibitors of carcinogenesis. Planta Med. 2004;70:691-705.

107. Manigauha A, Kharya MD, Ganesh N. In vivo antitumor potential of Ipomoea pes-caprae on melanoma cancer. Pharmacogn Mag. 2015;11(42):426-33.

108. Murray B, Carter R, Imrie C, Evans S, O'Suilleabhain C. Diclofenac reduces the incidence of acute pancreatitis after endoscopic retrograde cholangiopancreatography. Gastroenterology. 2003;124(7):1786-91.

109. Weber G, Shen F, Prajda N. Increased signal transduction activity and down-regulation in human cancer cells. Anticancer Res. 1996;16(6A):271-3282. 
110. Fotsis T, Pepper MS, Aktas EE. Flavonoids, dietary derived inhibitors of cell proliferation and in vitro angiogenesis. Cancer Res. 1997;57(14):2916-21.

111. Mishra A, Sharma AK, Kumar S, Saxena AK, Pandey AK. Bauhinia variegata leaf extracts exhibit considerable antibacterial, antioxidant, and anticancer activities. BioMed Res Intern. 2013;(2013):article Id 915436:1-10.

112. Kumar S, Pandey AK. Chemistry and biological activities of flavonoids: An Overview. Sci World J. 2013;2013:article Id 162750:(1-16).

113. Agrawal RC, Jain R, Raja W, Ovais M. Anticarcinogenic effects of Solanum lycopersicum fruit extract on Swiss albino and C57BL mice. Asian Pac J Cancer Prev. 2009;10:379-82.

114. Raja W, Agrawal RC, Ovais M. Chemopreventive action of Lawsonia inermis leaf extract on DMBA-induced skin papilloma and B16F10 melanoma tumour. Pharmacologyonline. 2009;2:1243-9.

115. Pandey S, Agrawal RC. Chemopreventive potential of Bauhinia variegate flower extract against DMBA-induced skin Papillomagenesis in mice. Pharmacologyonline. 2010;1:39-46.

116. Suzuki F, Kobayashi M, Komatsu Y, Kato A, Pollard RB. Keishi-ka-kei-to, a traditional Chinese herbal medicine: inhibits pulmonary metastasis of B16 melanoma. Anticancer Res. 1997;17(2A):873-8.

\section{Submit your next manuscript to BioMed Central} and we will help you at every step:

- We accept pre-submission inquiries

- Our selector tool helps you to find the most relevant journal

- We provide round the clock customer support

- Convenient online submission

- Thorough peer review

- Inclusion in PubMed and all major indexing services

- Maximum visibility for your research

Submit your manuscript at www.biomedcentral.com/submit 